University of Nebraska - Lincoln

DigitalCommons@University of Nebraska - Lincoln

Faculty Papers and Publications in Animal

Science

Animal Science Department

March 1996

\title{
Effect of Selection for Size of Testes in Boars on Semen and Testis Traits
}

Ying-Tsorn Huang

University of Nebraska-Lincoln

Rodger K. Johnson

University of Nebraska-Lincoln, rjohnson5@unl.edu

Follow this and additional works at: https://digitalcommons.unl.edu/animalscifacpub

Part of the Animal Sciences Commons

Huang, Ying-Tsorn and Johnson, Rodger K., "Effect of Selection for Size of Testes in Boars on Semen and Testis Traits" (1996). Faculty Papers and Publications in Animal Science. 94.

https://digitalcommons.unl.edu/animalscifacpub/94

This Article is brought to you for free and open access by the Animal Science Department at DigitalCommons@University of Nebraska - Lincoln. It has been accepted for inclusion in Faculty Papers and Publications in Animal Science by an authorized administrator of DigitalCommons@University of Nebraska - Lincoln. 


\title{
Effect of Selection for Size of Testes in Boars on Semen and Testis Traits ${ }^{1,2}$
}

\section{Ying-Tsorn Huang 3 and Rodger K. J ohnson 4}

\author{
Department of Animal Science, University of Nebraska, Lincoln 68583-0908
}

\begin{abstract}
The objective of this study was to evaluate the effects of selection for increased size of testes on semen and testis characteristics. Boars from a line selected for increased size of testes at $150 \mathrm{~d}$ of age (TS, $n=25$ ) and a randomly selected control line $(C, n=18)$ were used. Semen was collected three times per week for 3 wk (TRT1) then daily for 3 wk (TRT2) beginning when boar age averaged $276 \mathrm{~d}$. It was followed by a 4-wk period of one collection per week and then the TRT1-TRT2 sequence was repeated. After 64 collections, boars were castrated and testes were evaluated for sperm numbers. Volume of semen, percentage of motile sperm cells, and percentage of abnormal cells in the semen did not differ $(P>.05)$ between lines. Concentration of sperm cells in the semen was greater for TS boars at TRT 1 (35.0 million cells $/ \mathrm{mL}, \mathrm{P}<.10)$ and TRT 2 (29.5
\end{abstract}

million cells $/ \mathrm{mL}, \mathrm{P}<.01$ ). Number of sperm cells per ejaculate was greater for TS boars (6.1 and 4.3 billion cells for TRT 1 and TRT 2, respectively; $P<.05$ ). Percentage of abnormal cells was less $(P<.05)$ for boars at the younger ages. Concentration of sperm cells was 16 to 18 million cells/mL semen greater $(P<$ .05 ) at the older ages. Significant differences in the shapes of the response curves with increasing collection number across lines and ages were found. These differences were small and not considered to be important. Line differences in testicular and epididymal sperm numbers and in daily sperm production were consistent with differences in semen traits. Repeatabilities of semen traits were between .16 and .74. Selection for increased size of testes can be used to improve the reproductive capacity of boars used for artificial insemination.

Key Words: Boars, Testes, Semen, Selection

\section{Introduction}

Testicular size in boars is highly heritable (Legault et al., 1980; Neely et al., 1980; Young et al., 1986; J ohnson et al., 1994). Testis size and weight are correlated with daily sperm production and total sperm reserves ( $F$ ent et al., 1983; Young et al., 1986; Lubritz et al., 1991; Rathje et al., 1995). The present experiment was done to test the hypothesis that selection for larger testes improves fertility and reproductive efficiency in boars. Such improvements would be valuable to pig producers, especially those using artificial insemination.

\footnotetext{
${ }^{1}$ Published as paper no. 11212, J ournal Ser., Nebraska Agric. Res. Div., Univ. of Nebraska, Lincoln 68583-0908.

${ }^{2}$ Research supported by the National Pork Producers Council, Des Moines, IA.

${ }^{3}$ Present address: Taiwan Sugar Company, No. 80, Hsin Long Rd., Wanlun, Pingtun, Taiwan.

${ }^{4}$ To whom correspondence should be addressed.

Received J uly 24, 1995.

Accepted December 21, 1995.
}

Selection for increased size of testes at $150 \mathrm{~d}$ of age in boars was practiced for 10 generations (J ohnson et al., 1994). The objectives of this research were 1) to determine the correlated responses to this selection in volume of semen produced, percentage of motile sperm, percentage of abnormal sperm, and concentration of sperm in this semen when semen was collected three times per week and when collected daily from boars between the ages of 8.5 to $13.5 \mathrm{mo}, 2$ ) to compare testicular and epididymal sperm reserves and daily rates of sperm production in boars of the select and control lines, and 3) to estimate repeatabilities of semen traits.

\section{Materials and Methods}

Population and Animals. Boars for this experiment were from the 10th and 11th generations of lines that were selected for increased size of testes. Design of the selection experiment and responses to selection have been reported (J ohnson et al., 1994); therefore, only a general description will be given here. 
The population was a Landrace-Large White composite formed in 1979 and then randomly mated for three generations before selection was initiated in 1981. The base generation for the selection experiment was established by randomly assigning F 3-generation littermates to the select (TS) and control (C) lines. There were 40 to 45 litters by 15 sires per line each generation. Mass selection among boars and random, within-full-sib family selection among gilts were practiced in the TS line. Random selection within halfsib family (boars) or full-sib family (gilts) was practiced in the $\mathrm{C}$ line. The selection criterion was weight of testes at $150 \mathrm{~d}$ of age predicted from width and length of paired testes measured with a calipers when boars were 140 and $160 \mathrm{~d}$ of age (J ohnson et al., 1994).

Realized heritability of predicted weight of testes was .35, and response per generation averaged $5.5 \%$ of the base generation mean (J ohnson et al., 1994). Predicted weight of testes averaged 555.7 and $337.4 \mathrm{~g}$ for TS and C boars, respectively, at generation 10 . Boars used in the present experiment were random samples from within half-sib families of the 10th and the 11th generations.

Thirty $C$ boars were selected at weaning and left as boars in Generation 10; the remaining male pigs were castrated. Twenty-two of the boars were retained for breeding, so only eight were available for this experiment. More C boars were left intact in Generation 11. After breeders were designated, 17 boars were available for this experiment. All TS boars were left intact. A random sample of them was first designated for this experiment (22 in Generation 10 and 21 in Generation 11) and then breeders for the selection experiment were selected.

Management and Traits Measured. Pigs were weaned at $28 \mathrm{~d}$ of age and placed in raised-deck nursery pens where they were fed a corn-soybean meal diet with $18 \%$ crude protein. At $56 \mathrm{~d}$ of age, they were removed from the nursery and placed in a modified open-front building. Boars were housed separately from gilts in groups of 10 pigs per pen. They were fed a $16 \%$ crude protein diet to $60 \mathrm{~kg} \mathrm{BW}$, after which a $14 \%$ crude protein diet was fed.

Boars were transported from the swine unit at the Agricultural Research and Development Center, Mead, to the Animal Science Building, Lincoln. They were housed in a room containing 24 pens, a semen collection pen, and a laboratory equipped for processing semen. They were fed approximately $2.5 \mathrm{~kg}$ per day of a $14 \%$ crude protein diet. Room temperature was maintained at approximately $20^{\circ} \mathrm{C}$.

Boars were trained to mount a dummy, which was inside the collection area in a space $2.5 \times 2 \mathrm{~m}$. The sample of eight $C$ and 22 TS boars from Generation 10 $(\mathrm{Yr} 1)$ began the training period when they averaged $185.4 \mathrm{~d}$ of age (range 175 to $212 \mathrm{~d}$ ). After $80 \mathrm{~d}$, six C and 14 TS boars regularly mounted the dummy and ejaculated. The sample of $17 \mathrm{C}$ and 21 TS boars from
Generation 11 ( $Y$ r 2) averaged $219.7 \mathrm{~d}$ of age (range 185 to $238 \mathrm{~d}$ ) at the beginning of the training period. Twelve $C$ and 11 TS boars regularly mounted the dummy and ejaculated. Those boars that regularly mounted the dummy and ejaculated, $18 \mathrm{C}$ and $25 \mathrm{TS}$ boars, were used in the experiment. The difference of $34 \mathrm{~d}$ in age of boars between years was due to timing when the experimental room was available and to random sampling.

After the training period, semen was collected three times per week (TRT 1) for 3 wk followed by daily collections (TRT 2) for another 3 wk. Semen was collected on Monday, Wednesday, and Friday, or Tuesday, Thursday, and Saturday while boars were on TRT 1. A random order in which semen was collected from boars was established and this order remained the same throughout the experiment, except that the boar collected first each day was rotated sequentially. The order in which collections were made was $1,2,3$, ..., 20 on the first day; $2,3, \ldots, 20,1$ the second day, etc. Semen was collected from each boar once per week for 4 wk after TRT 2 was completed, which resulted in at least a 35-d rest period. Following the rest period, boars repeated TRT 1 for 3 wk followed by TRT 2 for 3 wk.

The mean, standard deviation, and range in ages of boars at the beginning of each collection period are given in Table 1 . Number of potential semen collections and number of successful collections in each period are also given. Number of potential semen collections was calculated assuming that each boar that entered a period regularly mounted the dummy and ejaculated as scheduled. Three boars were re moved from the experiment before its completion. One was injured during Period 2 of yr 1 . Semen was collected from this boar seven times during wk 1 before its injury. Therefore, 14 of the 19 failures in this period were for this boar. Blood appeared in the semen of two boars during the experiment. No attempt was made to collect semen from these boars after this occurred. One of these boars was in Period 3 of $\mathrm{yr} 1$. Semen was collected from him only once in that period, and he accounted for all of the failures in the period. The other boar was in Period 5 of $y r 2$. This boar accounted for two of the failures for that period.

Failures of boars to mount the dummy and ejaculate were not considered to be problems in the experiment. Semen was collected 64 times as scheduled for 30 of the 43 boars. Most of the failures occurred during the last 3-wk period (Period 5). Three boars stopped mounting the dummy during Period 5, after which no further semen was collected from them, and they accounted for 26 of the failures during Period 5. Three boars had four consecutive failures, and one boar had three consecutive failures, after which semen was again collected regularly from these boars. Otherwise, failures of boars to mount the dummy and ejaculate occurred sporadically throughout the experi- 
Table 1. Means, standard deviations, and range (minimum to maximum) for age of boars at the beginning of each collection treatment, and number of potential semen collections and number of successful collections in each period

\begin{tabular}{|c|c|c|c|c|c|c|c|}
\hline \multirow{2}{*}{$\begin{array}{l}\text { Treatment } \\
\text { (collections/wk) }\end{array}$} & \multirow[b]{2}{*}{ Period $^{a}$} & \multirow[b]{2}{*}{$\mathrm{n}$} & \multicolumn{3}{|c|}{ Age, $d$} & \multicolumn{2}{|c|}{ No. of collections } \\
\hline & & & Mean & SD & Range & Potential & Successful \\
\hline & & & & Yr: & & 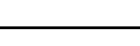 & - \\
\hline 3 & 1 & 20 & 266.4 & 9.6 & $256-293$ & 180 & 179 \\
\hline 7 & 2 & 20 & 287.4 & 9.6 & $277-314$ & 420 & $401^{b}$ \\
\hline 1 & 3 & 19 & 314.9 & 9.5 & $304-341$ & 76 & 74 \\
\hline 3 & 4 & 19 & 345.9 & 9.5 & $335-372$ & 171 & $162^{c}$ \\
\hline 7 & 5 & 18 & 363.7 & 9.7 & $353-390$ & 378 & 353 \\
\hline Castration & & 19 & 388.8 & 9.5 & $378-415$ & - & - \\
\hline 3 & 1 & 23 & 285.7 & 15.9 & 251-304 & 207 & 204 \\
\hline 7 & 2 & 23 & 306.7 & 15.9 & $272-325$ & 483 & 483 \\
\hline 1 & 3 & 23 & 334.7 & 15.9 & $300-353$ & 92 & 92 \\
\hline 3 & 4 & 23 & 362.7 & 15.8 & $328-381$ & 207 & $201^{d}$ \\
\hline 7 & 5 & 22 & 382.9 & 15.8 & $349-402$ & 462 & 449 \\
\hline Castration & & 23 & 408.7 & 15.9 & $374-427$ & - & - \\
\hline
\end{tabular}

aperiods 1, 2, 4, and 5 were 3 wk in length, period 3 was 4 wk.

bone boar was injured and removed from the experiment after wk 1 of this period.

cone boar had blood in the semen and was removed from the experiment after one collection in wk 1 of this period.

dOne boar had blood in the semen and was removed from the experiment after one collection in wk 3 of this period.

ment and were immediately followed by regular collections.

All semen was collected and volume of the spermrich fraction, the viscous-chalky, milky-white portion that contains 80 to $90 \%$ of the spermatozoa, was recorded immediately upon completion of semen collection from each boar. Samples of semen were used to determine percentage of motile sperm, percentage of abnormal sperm, concentration of sperm, and total number of sperm per ejaculate. Each boar, except the one that was injured, was castrated at the end of the experiment and the right testis and epididymis were used to determine total testicular sperm, daily sperm production, and total epididymal sperm reserves.

Sperm motility was estimated subjectively immediately after collection of semen. A drop of semen was placed on a warmed microscope slide with a Pasteur disposable pipette and observed under magnification $(100 \times)$ with a light microscope. Progressive motility was estimated on a continuous scale of 0 to $100 \%$.

A drop of semen was placed on a warmed slide with a drop of Rose-Bengal staining solution ( $3 \mathrm{~g}$ powdered Rose-Bengal stain, $1 \mathrm{~mL} 40 \%$ Formalin, $99 \mathrm{~mL}$ distilled water) and examined for sperm abnormalities. After mixing, a cover glass was positioned carefully on the slide to evenly spread the sample across the end of the slide. The morphology of 10 sperm in 10 different microscopic fields was classified for each slide. The number of abnormal sperm was expressed as a percentage of the total number observed. Forms of sperm classified as abnormal were piriform head, tapering head, narrow head, small head, giant head, short wide head, coiled tail, abnormal attachment of midpiece, distal plasmic droplet, proximal plasmic droplet, tailless sperm, and doubleheaded sperm as described by Sorensen (1979).

Concentration of sperm in the sperm-rich fraction of the ejaculate was determined with a spectrophotometer by the method described by Young et al. (1960). The wavelength was set at $530 \mathrm{~nm}$. A mixed solution of $3.9 \mathrm{~mL}$ of sodium citrate and $.1 \mathrm{~mL}$ of semen was placed into the curvet. Each sample was measured in duplicate. A 3.9-mL solution of cobalt chloride was used as a standard solution to calibrate the spectrophotometer. Total number of sperm per ejaculate was determined by multiplying the sperm concentration by the volume of sperm-rich fraction.

After castration, the epididymis was trimmed from the testis and trimmed testis weight was obtained for each boar. The testis was decapsulated and weight of the parenchyma was recorded. Three 1-g samples of parenchymal tissue representing the proximal, mid, and distal regions of the testis were removed and frozen for later processing. Vasculature was removed from the epididymis. Weight of the epididymis was recorded. The cauda epididymis was separated, weighed, and frozen for later processing.

Procedures used to determine daily sperm production were based on enumeration of homogenizationresistant sperm nuclei as described by Amman and Almquist (1961). The exact protocol used was described by Rathje et al. (1995). Sperm numbers in the cauda epididymis were estimated using the same technique. The number of mature sperm nuclei was counted in duplicate using a hemacytometer. An estimate of total mature sperm cells per gram of cauda epididymis was obtained.

Data Analyses. The design of the experiment was a split-plot; multiple measures were taken on each boar 
Table 2. Probabilities that regression coefficients on orthogonal polynomials of collection number differ from zero ${ }^{a}$

\begin{tabular}{|c|c|c|c|c|c|}
\hline Item & $\begin{array}{l}\text { Semen } \\
\text { volume }\end{array}$ & $\begin{array}{l}\text { Motile } \\
\text { sperm }\end{array}$ & $\begin{array}{l}\text { Abnormal } \\
\text { sperm }\end{array}$ & $\begin{array}{c}\text { Sperm } \\
\text { concentration }\end{array}$ & $\begin{array}{l}\text { No. of } \\
\text { sperm }\end{array}$ \\
\hline & \multicolumn{5}{|c|}{ TRT1: three collections per week } \\
\hline Linear ( L ) & $<01$ & $<01$ & .01 & $<01$ & $<01$ \\
\hline Quadratic (Q) & $<05$ & $<01$ & NS & $<01$ & $<01$ \\
\hline $\mathrm{L} \times$ line & $<10$ & NS & NS & NS & NS \\
\hline$L \times$ age & NS & NS & NS & $<01$ & $<01$ \\
\hline $\mathrm{Q} \times$ line & NS & NS & NS & NS & NS \\
\hline $\mathrm{Q} \times$ age & NS & NS & .05 & $<01$ & $<01$ \\
\hline Linear ( $\mathrm{L}$ ) & $<01$ & $<01$ & $<01$ & $<01$ & $<01$ \\
\hline Quadratic (Q) & $<01$ & $<01$ & $<01$ & $<01$ & $<01$ \\
\hline $\mathrm{L} \times$ line & $<01$ & NS & NS & $<01$ & $<01$ \\
\hline $\mathrm{L} \times$ age & $<10$ & $<01$ & $<10$ & .05 & $<01$ \\
\hline $\mathrm{Q} \times$ line & NS & NS & NS & NS & NS \\
\hline $\mathrm{Q} \times$ age & NS & $<05$ & NS & NS & NS \\
\hline
\end{tabular}

${ }^{\mathrm{a}} \mathrm{NS}=$ not significant $(\mathrm{P}>.10)$.

over time. The observations on boars are not independent. To account for this correlated structure among data, statistical analyses were performed with the PROC MIXED general linear models procedure (SAS, 1992). This procedure fits mixed linear models, those with both fixed and random effects as occur in splitplot designs, and produces appropriate standard errors for all estimable linear combinations of fixed and random effects, and corresponding t- and F-tests. Restricted Maximum Likelihood estimates of variance components are computed. This procedure takes into account the correlated structure of observations within boars. An assumption of the model is that boars are unrelated.

All the traits measured on semen collections were analyzed by treatments. Data for TRT 1 were fitted to a mixed model that included the fixed effects of line ( L), year $(\mathbf{Y}), \mathbf{L} \times \mathbf{Y}$, period (P) (semen collected during the first 3 wk were assigned to $P 1$, semen collected during the second 3 wk were assigned to $\mathrm{P} 2)$, $\mathrm{P} \times \mathrm{Y}, \mathrm{P} \times \mathrm{L}, \mathrm{P} \times \mathrm{Y} \times \mathrm{L}$, collection number $(\mathbf{C N}$ ) (nine collections in each period in TRT 1 ), $C N \times Y, C N \times L$, $C N \times P, C N \times Y \times L, C N \times P \times L$, and the random effects of boar ( B) within $Y \times L$ and $P \times B$ within $Y \times$ $L$. Linear contrasts were used to determine regressions on orthogonal linear and quadratic polynomials for collection number and the interaction of these regressions with line and period (see footnotes to Table 3 for the specific contrasts used).

Data for TRT 2 were fitted to the same model, except the $\mathrm{CN} \times \mathrm{P} \times \mathrm{L}$ and $\mathrm{CN} \times \mathrm{Y} \times \mathrm{L}$ interactions were deleted from the model because they were not significant in preliminary analyses. There were 21 collections per period in TRT 2 .

Period effects were considered to be due primarily to age of boar and, therefore, are called age effects in the discussion below. During TRT 1 boars averaged $276 \mathrm{~d}$ of age at the beginning of Period 1 and $354 d$ at the beginning of Period 2. They averaged $297 \mathrm{~d}$ at the beginning of Period 1 and $373 \mathrm{~d}$ at the beginning of Period 2 during TRT 2.

Variance components for $\mathrm{B}$ within $\mathrm{Y} \times \mathrm{L}\left(\sigma_{\mathrm{B}}^{2}\right), \mathrm{P} \times \mathrm{B}$ $\left(\sigma_{\mathrm{AB}}^{2}\right)$, and residual $\left(\sigma_{\mathrm{R}}^{2}\right)$ were estimated for each TRT. Within TRT, repeatabilities were calculated as $\hat{o}_{\mathrm{B}}^{2} /\left(\hat{o}_{\mathrm{B}}^{2}+\hat{o}_{\mathrm{AB}}^{2}+\hat{o}_{\mathrm{R}}^{2}\right)$.

Data for testicular traits (weights of trimmed testis, epididymis, tunica, parenchyma, and total testicular sperm, daily sperm production, and total sperm reserves), for which there was one observation per boar, were fitted to a model that included the effects of line $(L)$, year $(Y)$, and $L \times Y$. The residual, which is the variance among boars, was used to test all effects.

\section{Results}

Probabilities for tests of significance of linear and quadratic regressions on orthogonal polynomials and interactions of these regressions with line and age for each trait are given in Table 2 . Table 3 contains the regression coefficients. Subclass regressions within treatments are presented for those cases in which line $\times$ regression and(or) age $\times$ regression interactions were significant. Average regressions are presented if they were significant and if interactions with line and age were not important $(\mathrm{P}>.10)$.

Figures 1 to 5 contain plots of the least squares means and the response curves calculated with the coefficients in Table 3. The response curves were calculated as $Y=u_{L \times A}+b_{L} \cdot X_{1}+b_{Q} \cdot X_{2}$, where $u_{L \times A}$ is the least squares mean for the line-age subclass (Table 4), $b_{L}$ and $b_{Q}$ are the linear and quadratic regression coefficients, respectively (Table 3 ), and $X_{1}$ 
Table 3. Regression coefficients of orthogonal linear $\left(b_{\mathrm{L}}\right)$ and quadratic $\left(b_{Q}\right)$ polynomials for each line-age treatment ${ }^{a}$

\begin{tabular}{|c|c|c|c|c|c|c|c|c|}
\hline \multirow[b]{2}{*}{ Trait } & \multicolumn{4}{|c|}{ TRT1: three collections per week ${ }^{b}$} & \multicolumn{4}{|c|}{ TRT2: Daily collections ${ }^{c}$} \\
\hline & $C_{1}$ & $\mathrm{TS}_{1}$ & $\mathrm{C}_{4}$ & $\mathrm{TS}_{4}$ & $C_{2}$ & $\mathrm{TS}_{2}$ & $C_{5}$ & $\mathrm{TS}_{5}$ \\
\hline $\begin{array}{l}\text { Semen volume, } \mathrm{mL} \\
\mathrm{b}_{\mathrm{L}} \\
\mathrm{b}_{\mathrm{Q}}\end{array}$ & $\begin{array}{r}-3.44 \\
.13\end{array}$ & $\begin{array}{r}-1.98 \\
.13\end{array}$ & $\begin{array}{r}-3.44 \\
.13\end{array}$ & $\begin{array}{r}-1.98 \\
.13\end{array}$ & $\begin{array}{r}-1.00 \\
.037\end{array}$ & $\begin{array}{c}-.50 \\
.037\end{array}$ & $\begin{array}{r}-1.50 \\
.037\end{array}$ & $\begin{array}{c}-.72 \\
.037\end{array}$ \\
\hline $\begin{array}{l}\text { Motile sperm, \% } \\
b_{\mathrm{L}} \\
\mathrm{b}_{\mathrm{O}}\end{array}$ & $\begin{array}{c}-.19 \\
.024\end{array}$ & $\begin{array}{c}-.19 \\
.024\end{array}$ & $\begin{array}{c}-.19 \\
.024\end{array}$ & $\begin{array}{c}-.19 \\
.024\end{array}$ & $\begin{array}{r}-.403 \\
.018\end{array}$ & $\begin{array}{r}-.403 \\
.018\end{array}$ & $\begin{array}{r}-.281 \\
.011\end{array}$ & $\begin{array}{r}-.281 \\
.011\end{array}$ \\
\hline $\begin{array}{l}\text { Abnormal sperm, \% } \\
\mathrm{b}_{\mathrm{L}} \\
\mathrm{b}_{\mathrm{Q}}\end{array}$ & $\begin{array}{l}.073 \\
.006\end{array}$ & $\begin{array}{l}.073 \\
.006\end{array}$ & $\begin{array}{r}.073 \\
-.010\end{array}$ & $\begin{array}{r}.073 \\
-.010\end{array}$ & $\begin{array}{l}.109 \\
.002\end{array}$ & $\begin{array}{l}.109 \\
.002\end{array}$ & $\begin{array}{l}.079 \\
.002\end{array}$ & $\begin{array}{l}.079 \\
.002\end{array}$ \\
\hline $\begin{array}{l}\text { Sperm million } / \mathrm{mL} \\
\mathrm{b}_{\mathrm{L}} \\
\mathrm{b}_{\mathrm{Q}}\end{array}$ & $\begin{array}{r}-17.68 \\
1.26\end{array}$ & $\begin{array}{r}-17.68 \\
1.26\end{array}$ & $\begin{array}{r}-22.99 \\
2.02\end{array}$ & $\begin{array}{r}-22.99 \\
2.02\end{array}$ & $\begin{array}{r}-3.22 \\
.15\end{array}$ & $\begin{array}{r}-4.11 \\
.15\end{array}$ & $\begin{array}{r}-3.83 \\
.15\end{array}$ & $\begin{array}{r}-4.90 \\
.15\end{array}$ \\
\hline $\begin{array}{l}\text { No. of sperm, billion } \\
b_{L} \\
b_{Q}\end{array}$ & $\begin{array}{r}-3.21 \\
.26\end{array}$ & $\begin{array}{r}-3.21 \\
.26\end{array}$ & $\begin{array}{r}-4.79 \\
.42\end{array}$ & $\begin{array}{r}-4.79 \\
.42\end{array}$ & $\begin{array}{r}-.62 \\
.03\end{array}$ & $\begin{array}{r}-.67 \\
.03\end{array}$ & $\begin{array}{r}-.67 \\
.03\end{array}$ & $\begin{array}{r}-.84 \\
.03\end{array}$ \\
\hline
\end{tabular}

${ }^{\mathrm{a}} \mathrm{C}=$ control line, TS =testis size line, and subscripts $1,2,4$, and 5 represent average ages of 287, 308, 365, and 384 d, respectively, for each period.

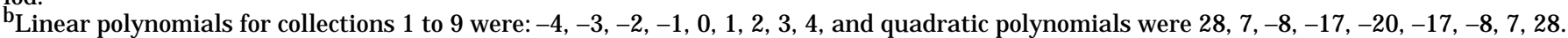

Cinear polynomials for collections 1 to 21 were: $-10,-9,-8,-7,-6,-5,-4,-3,-2,-1,0,1,2,3,4,5,6,7,8,9$, 10, and quadratic polynomials were $190,133,82,37,-2,-35,-62,-83,-98,-107,-110,-107,-98,-83,-62,-35,-2,37,82,133,190$.

Table 4. Least squares means and contrasts among means for each treatment

\begin{tabular}{|c|c|c|c|c|c|c|}
\hline \multirow[b]{2}{*}{ Line $^{\mathrm{a}}$} & \multirow[b]{2}{*}{$\mathrm{Age}^{\mathrm{b}}$} & \multicolumn{5}{|c|}{ Trait } \\
\hline & & $\begin{array}{c}\text { Semen volume, } \\
\mathrm{mL}\end{array}$ & $\begin{array}{c}\text { Motile } \\
\text { sperm, \% }\end{array}$ & $\begin{array}{l}\text { Abnormal } \\
\text { sperm, \% }\end{array}$ & $\begin{array}{c}\text { Sperm } \\
\text { concentration, } \\
\text { million/mL }\end{array}$ & $\begin{array}{c}\text { No. of } \\
\text { sperm, billion }\end{array}$ \\
\hline & & & TR & collections & week & - \\
\hline C & 1 & 173.6 & 82.0 & 6.0 & 236.1 & 38.1 \\
\hline TS & 1 & 163.4 & 82.7 & 4.2 & 274.5 & 43.1 \\
\hline $\mathrm{C}$ & 4 & 173.5 & 81.0 & 7.6 & 257.4 & 41.6 \\
\hline TS & 4 & 172.3 & 82.1 & 6.0 & 289.0 & 48.7 \\
\hline $\mathrm{TS}-\mathrm{C}$ & & -5.7 & .9 & -1.7 & $35.0^{\dagger}$ & $6.1^{*}$ \\
\hline Age 1-Age 4 & & -4.4 & .7 & $-1.7^{*}$ & $-17.9 *$ & $-4.6^{*}$ \\
\hline \multirow[t]{2}{*}{ Interaction ${ }^{\mathrm{C}}$} & & -9.0 & -.4 & -.2 & 6.8 & -2.1 \\
\hline & & \multicolumn{5}{|c|}{ _ Rest period: one collection per week } \\
\hline C & 3 & 193.1 & 84.7 & 6.3 & 355.4 & 64.0 \\
\hline TS & 3 & 186.9 & 83.4 & 5.9 & 409.7 & 74.2 \\
\hline $\mathrm{TS}-\mathrm{C}$ & & -6.2 & -1.3 & -.4 & $54.3^{* *}$ & $14.2 * *$ \\
\hline C & 2 & 145.3 & 72.8 & 6.7 & 118.3 & 16.2 \\
\hline TS & 2 & 138.0 & 74.6 & 5.2 & 148.7 & 19.6 \\
\hline $\mathrm{C}$ & 5 & 140.8 & 76.7 & 8.2 & 135.2 & 18.0 \\
\hline TS & 5 & 147.4 & 78.5 & 7.0 & 163.8 & 23.2 \\
\hline $\mathrm{TS}-\mathrm{C}$ & & -.3 & 1.8 & -1.4 & $29.5^{* *}$ & $4.3^{* *}$ \\
\hline Age 2 -Age 5 & & -2.5 & $-3.9 * *$ & $-1.6 *$ & $-16.0^{* *}$ & $-2.7 * *$ \\
\hline Interaction ${ }^{c}$ & & $-13.9 *$ & 0 & -.3 & 1.8 & -1.8 \\
\hline
\end{tabular}

${ }^{\mathrm{a} C}=$ control line, $\mathrm{TS}=$ testis size line.

${ }^{b}$ Average ages of boars at the beginning of each treatment period are given in Table 1.

${ }^{\mathrm{C} C o n t r a s t:}$ (TS - C at the younger age) - (TS - C at the older age).

$\dagger_{\mathrm{P}}<.10$

$* P<.05$.

$* * P<.01$. 
and $\mathrm{X}_{2}$ are the linear and quadratic orthogonal polynomials (Table 3 , footnote). Response curves were calculated within each treatment.

Semen Volume. Both the linear and quadratic regression coefficients were significant for TRT 1 , and there was a linear $\times$ line interaction $(P<.10)$. A greater negative linear coefficient was found for line $C$ than for line TS (Table 3). The shape of the response curves differed between lines and ages for TRT 2 (Table 2). Greater negative linear coefficients (Table 3 ) were found for line $C$ than for line TS $(P<.01)$ and for the first age than for the second age ( $P=.06)$. The quadratic coefficient did not differ between ages or lines.

Semen volume decreased with increasing number of collections during both treatments (Figure 1). The response equation for TRT 1 had a lower plateau at approximately midway through wk 3 of both periods (collections 8 and 43). Volume then declined further for TRT 2 until approximately the middle of wk 2 of each period (collections 21 and 56), when a lower plateau was reached. The lower plateau of semen volume of 120 to $140 \mathrm{~mL}$ was similar for boars at both ages.

Mean semen volume did not differ between lines or ages, nor was there an interaction between lines and ages, for TRT 1 (Table 4). Line $\times$ age interaction was significant for TRT 2. Average volume for TS boars was $7.3 \mathrm{~mL}$ less than for $C$ boars at the younger age but was $6.6 \mathrm{~mL}$ greater at the older age. Overall averages did not differ between lines or ages.

Motility. Percentage of motile sperm cells declined quadratically with increasing collection number for each treatment (Tables 2 and 3). Linear and quadratic coefficients for TRT 1 did not differ between lines or ages, but both linear and quadratic coefficients for TRT 2 differed $(P<.05)$ between ages. Greater negative linear coefficients and greater positive quadratic coefficients were found for boars at the younger age (Table 3).

Percentage of motile sperm declined with increasing collection number until approximately the end of wk 2 in both periods (collections 6 and 40), when a lower plateau was reached for TRT 1 (Figure 2). Percentage of motile sperm declined further for TRT 2 until the end of wk 2 in both periods (collections 23 and 57), when a lower plateau occurred. The rate of decline was greater and the plateau less for younger than for older boars.

Mean percentage of motile sperm did not differ between lines or ages for TRT 1 (Table 4). Line means did not differ significantly, but percentage of motile sperm was $3.9 \%$ greater $(P<.01)$ for boars at the older age for TRT 2.

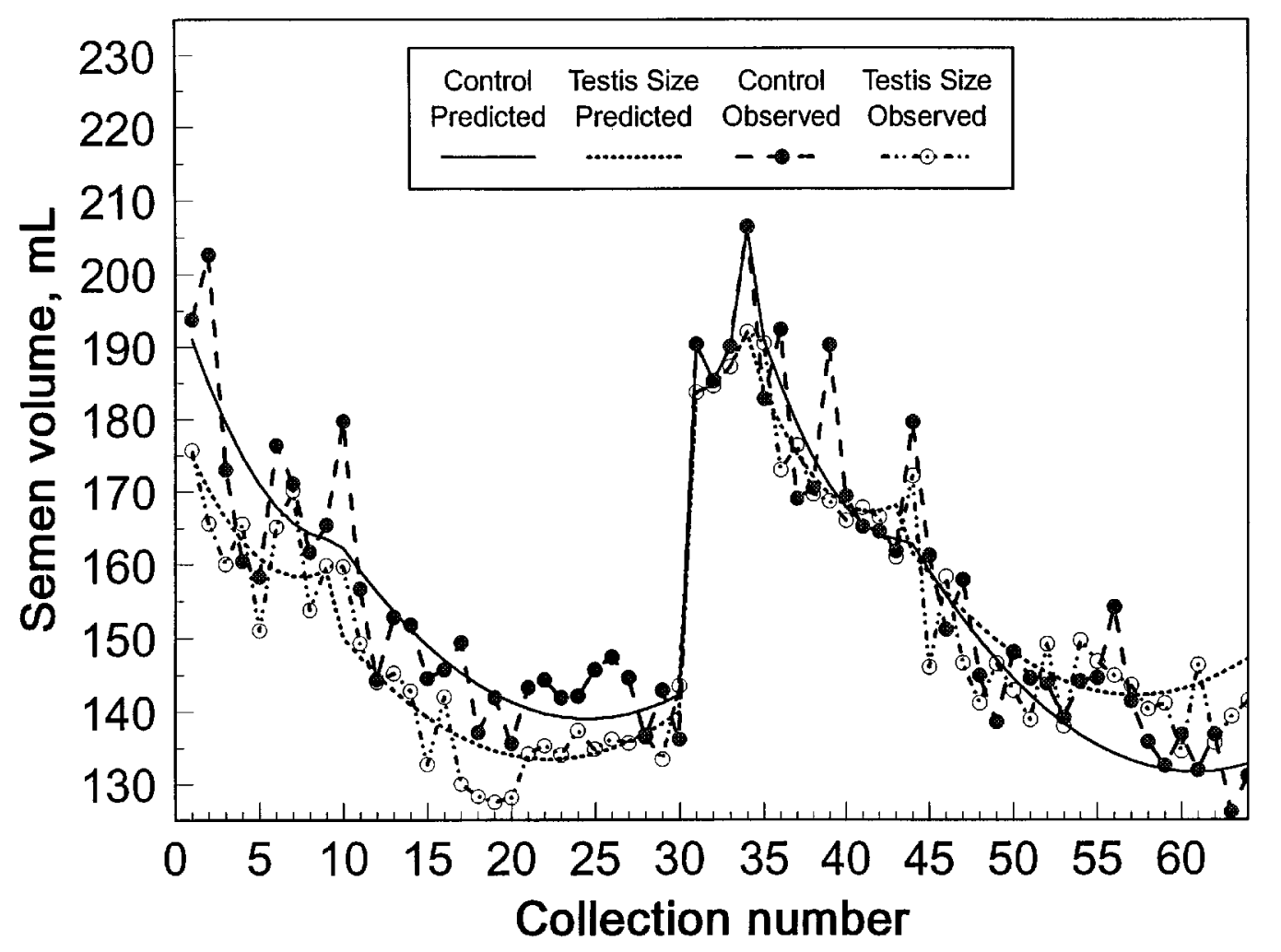

Figure 1. Observed and predicted volume of semen for the select (TS) and control (C) line boars. Collection numbers 1 to 9 and 35 to 43 are TRT1, three semen collections per week, numbers 10 to 30 and 44 to 64 are TRT2, daily semen collections, and 31 to 34 are the rest period, one semen collection per week. 
Abnormal Sperm Cells. The percentage of abnormal sperm cells increased quadratically for each treatment (Tables 2 and 3 ). Interactions of regression coefficients with line were not significant, but quadratic coefficients differed between ages for TRT 1 ( $P=.05$ ), and linear coefficients differed between ages for TRT 2 $(P<.10)$. The quadratic coefficient was positive for younger boars and negative for older boars for TRT 1 (Table 3). Linear regression coefficients were greater for younger boars than for older boars for TRT 2 .

Percentage of abnormal sperm increased with increasing collection number for each treatment (Figure 3). The response equation produced an upper plateau midway through wk 2 for TRT 1 for boars at the older age (collection 41), but the shape of the curve was just the opposite for boars at the younger age. The equation did not give a plateau during either TRT 1 or TRT 2 for younger boars or during TRT 2 for older boars. The percentage of abnormal sperm dedined sharply during the rest period.

Mean percentage of abnormal sperm did not differ significantly between lines for either treatment (Table $4)$. Percentage of abnormal sperm was greater $(P<$ .05) for older boars for each treatment.

Number and Concentration of Sperm. Results of analyses of concentration of sperm and total number of sperm in the semen were similar (Table 2). Linear and quadratic coefficients were significant and both coefficients differed between ages $(P<.01)$ for TRT 1 . Greater negative linear coefficients and greater positive quadratic coefficients for boars at the older age were found (Table 3 ). Linear coefficients differed between ages and lines $(P<.05)$ for TRT 2 (Table 2 ). Greater negative coefficients were found for TS than for $C$ boars and for boars at the older age (Table 3 ).

Concentration of sperm and total number of sperm in the semen declined with increasing collection number but reached a lower plateau during wk 3 of each period (collections 8 and 41) of TRT 1 (Figures 4 and 5). Both concentration of sperm and number of sperm declined further for TRT 2 until a lower plateau was reached at the end of wk 2 (collections 23 and 56). Concentration and number of sperm increased rapidly during the rest period. The lower plateaus for older and younger boars were similar for both treatments.

Line TS boars had greater average concentration of sperm (35 million/mL, $\mathrm{P}<.10$ ) and more total sperm $(6.1$ billion, $\mathrm{P}<.05)$ in the semen than $\mathrm{C}$ boars for TRT 1 (Table 4). The differences in line means were greater during the rest period. Differences between line means were less for TRT 2, but TS boars still had greater average sperm concentration (29.5 million sperm per $\mathrm{mL}, \mathrm{P}<.05)$ and 4.3 billion more total sperm $(P<.01)$ in their semen than $C$ boars.

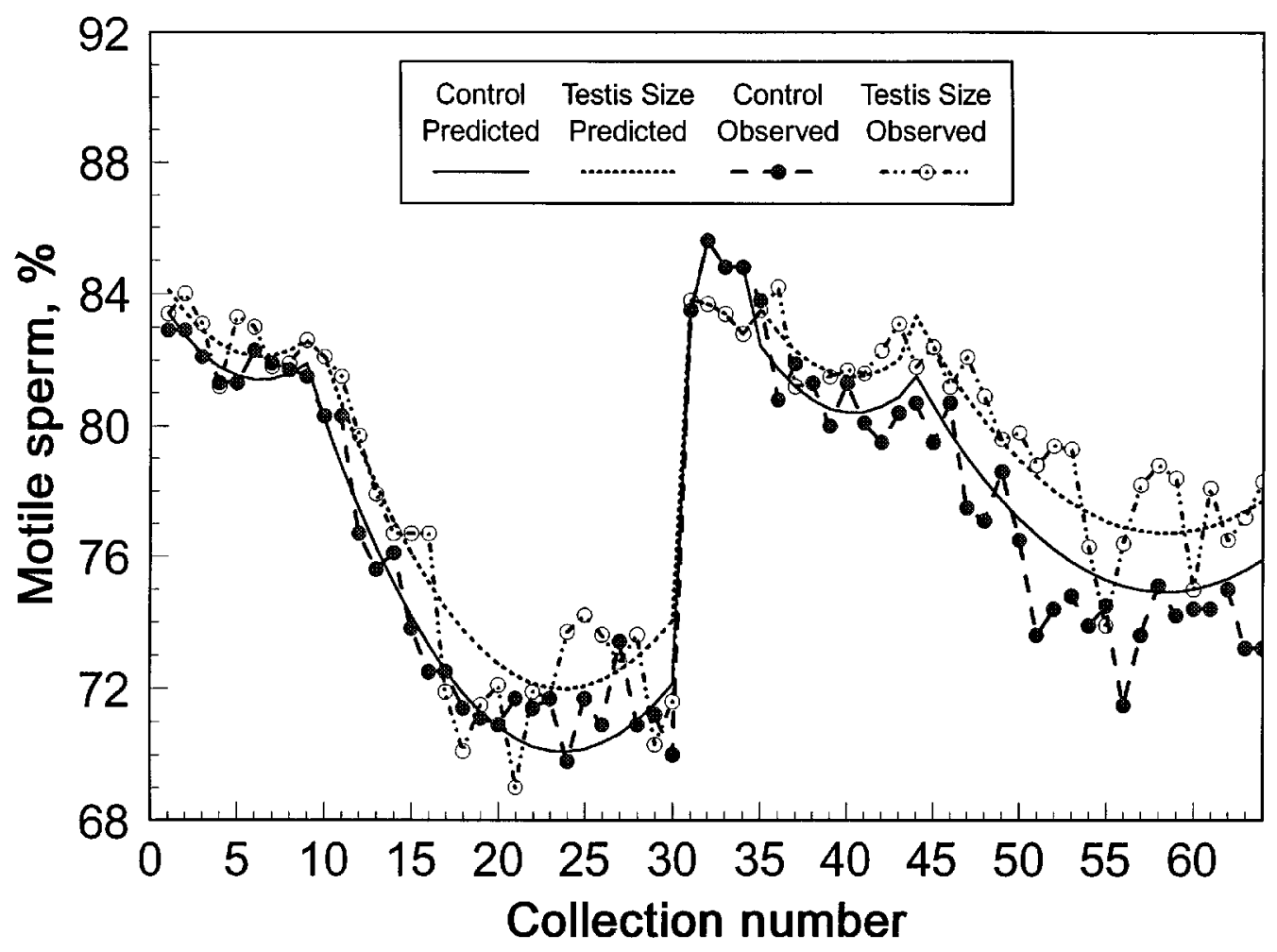

Figure 2. Observed and predicted percentage of motile sperm for the select (TS) and control (C) line boars. Collection numbers 1 to 9 and 35 to 43 are TRT1, three semen collections per week, numbers 10 to 30 and 44 to 64 are TRT2, daily semen collections, and 31 to 34 are the rest period, one semen collection per week. 


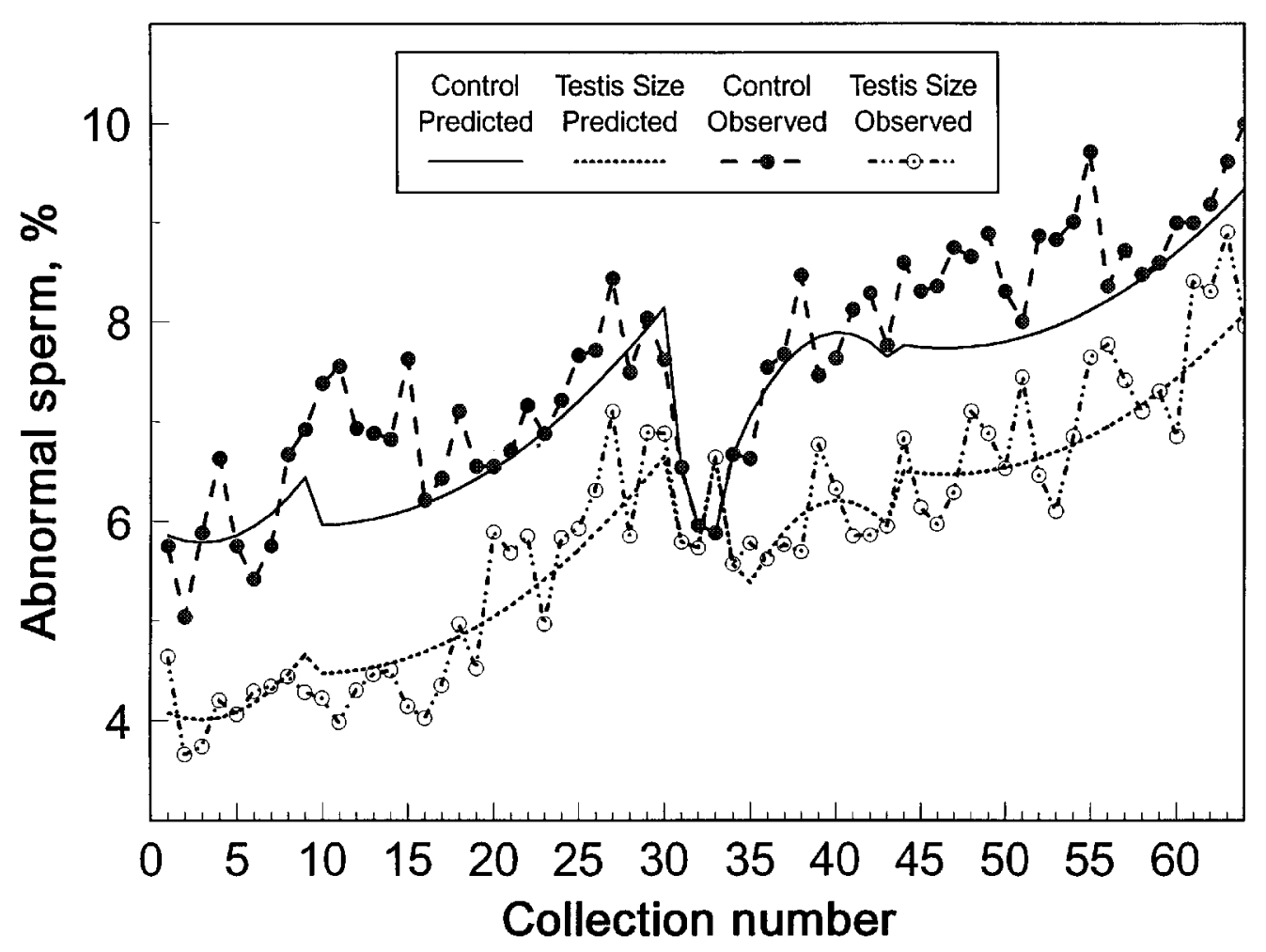

Figure 3. Observed and predicted percentage of abnormal sperm for the select (TS) and control (C) line boars. Collection numbers 1 to 9 and 35 to 43 are TRT1, three semen collections per week, numbers 10 to 30 and 44 to 64 are TRT2, daily semen collections, and 31 to 34 are the rest period, one semen collection per week.

Excised Testes. Comparisons of testicular traits between TS and $C$ boars after castration are given in Table 5. Body weight of boars did not differ between lines, but TS boars had greater means than $C$ boars for all traits of the testes $(P<.01)$. Line TS boars had larger testes (25.5\%) and epididymides (30.3\%), greater total testicular sperm numbers $(47.9 \%)$, greater rates of daily sperm production (48.3\%), and greater numbers of sperm in the cauda epididymis (36.7\%).

Variance Components. Components of variance for boar, boar $\times$ age, and residual and standard deviations and repeatabilities for each trait are given in Table 6. Standard deviations of semen volume, percentage of motile sperm, and percentage of abnormal sperm were similar for each treatment. Standard deviations of sperm concentration and number of sperm cells in the semen were greater for TRT 1 than for TRT 2 . Repeatabilities of traits were similar across treatments. They ranged from .37 to .74 for semen volume, percentage of abnormal sperm, percentage of motile sperm, and concentration of sperm cells in the semen. Repeatability of total number of sperm cells per collection was .26 for TRT 1 and .16 for TRT 2 .

\section{Discussion}

This experiment was designed to measure response curves in semen traits of TS and C boars at two regular semen collection frequencies beginning at ages of 276 (three collections per week) and $297 \mathrm{~d}$ (daily collections) and again when boars were $78 \mathrm{~d}$ older. Interactions of line $x$ regression coefficients were found for volume of semen and concentration and total number of sperm in the semen. Interactions of age $x$ regression coefficients were found for all traits except semen volume. However, differences in shapes of response curves for the lines and ages were small and not easily seen in the graphs. Further, there was a line $x$ age of boar interaction on means only for volume of semen for the treatment of daily semen collections. Therefore, the small differences in shapes of the response curves probably are not of either biological or economic importance.

Boars of the TS line produced semen with greater concentration of sperm and, therefore, produced more sperm at each collection than $\mathrm{C}$ boars. Differences between lines in the frequency of abnormal sperm and in percentage of motile sperm were not significant. 


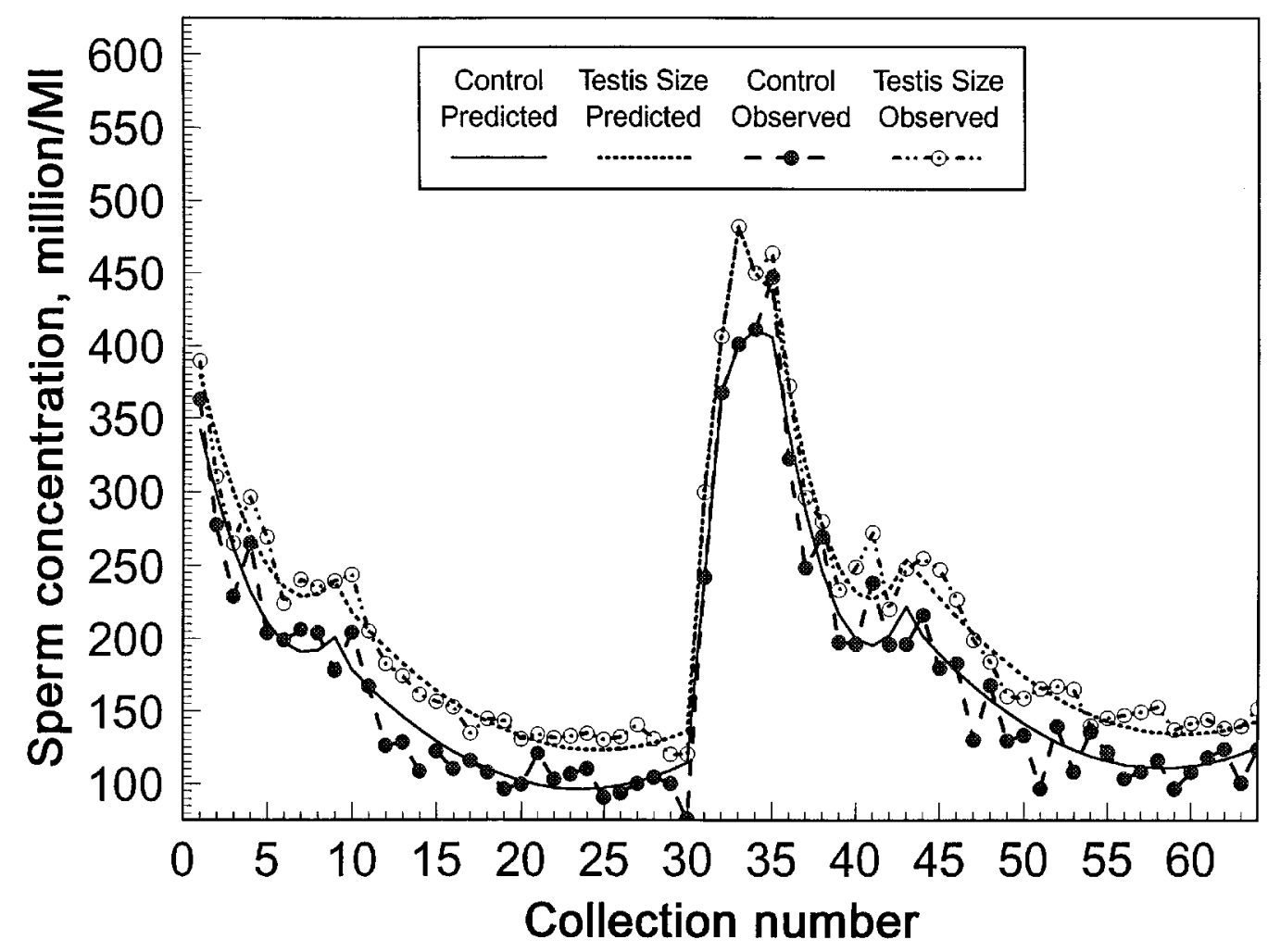

Figure 4. Observed and predicted concentration of sperm cells in the semen for the select (TS) and control (C) line boars. Collection numbers 1 to 9 and 35 to 43 are TRT1, three semen collections per week, numbers 10 to 30 and 44 to 64 are TRT2, daily semen collections, and 31 to 34 are the rest period, one semen collection per week.

Ejaculation frequency influences the time during which sperm are in the cauda epididymis and total sperm output (Amann, 1981). However, rate of sperm movement through the caput and corpus epididymis is not influenced by ejaculation (Amann and Almquist, 1962; Swierstra, 1971). Therefore, fertility of the sperm should not have been decreased even though fewer sperm were collected as collection number increased.

The advantage of line TS boars was 14.6 billion sperm during the period of one collection per week, 6.1 billion sperm during periods of three collections per week, and 4.3 billion sperm during periods of daily collections. Semen doses for artificial insemination in swine normally are diluted to contain 3 to 5 billion sperm per dose. From one to four more doses of semen could be prepared from each collection from TS than from C boars.

The increase in sperm output by TS boars was due to larger testes and to greater rates of daily sperm production. The advantage of TS boars compared to C boars in daily rate of sperm production estimated from

Table 5. Body weight of boars at castration and comparison of excised testes of $\mathrm{C}$ and TS boars

\begin{tabular}{lrr}
\hline \hline Characteristic & Line C & Line TS \\
\hline No. of boars & 18 & 24 \\
Average wt, kg & $169.8 \pm 3.1$ & $173.8 \pm 3.2$ \\
Trimmed testis wt, g & $286.5 \pm 13.7$ & $359.5 \pm 11.2^{* *}$ \\
Epididymis wt, g & $60.8 \pm 2.5$ & $79.2 \pm 2.1^{* *}$ \\
Tunica wt, g & $27.9 \pm 2.0$ & $36.2 \pm 1.6^{* *}$ \\
Parenchyma wt, g & $255.1 \pm 12.3$ & $318.0 \pm 10.1^{* *}$ \\
Total testicular sperm, billion & $39.0 \pm 2.9$ & $57.7 \pm 2.4^{* *}$ \\
Daily sperm production, billion & $8.9 \pm 0.7$ & $13.2 \pm 0.5^{* *}$ \\
Total sperm reserves, billion & $101.6 \pm 6.6$ & $138.9 \pm 5.4^{* *}$ \\
\hline
\end{tabular}

** Means for $\mathrm{C}$ and TS differ, $\mathrm{P}<.01$. 


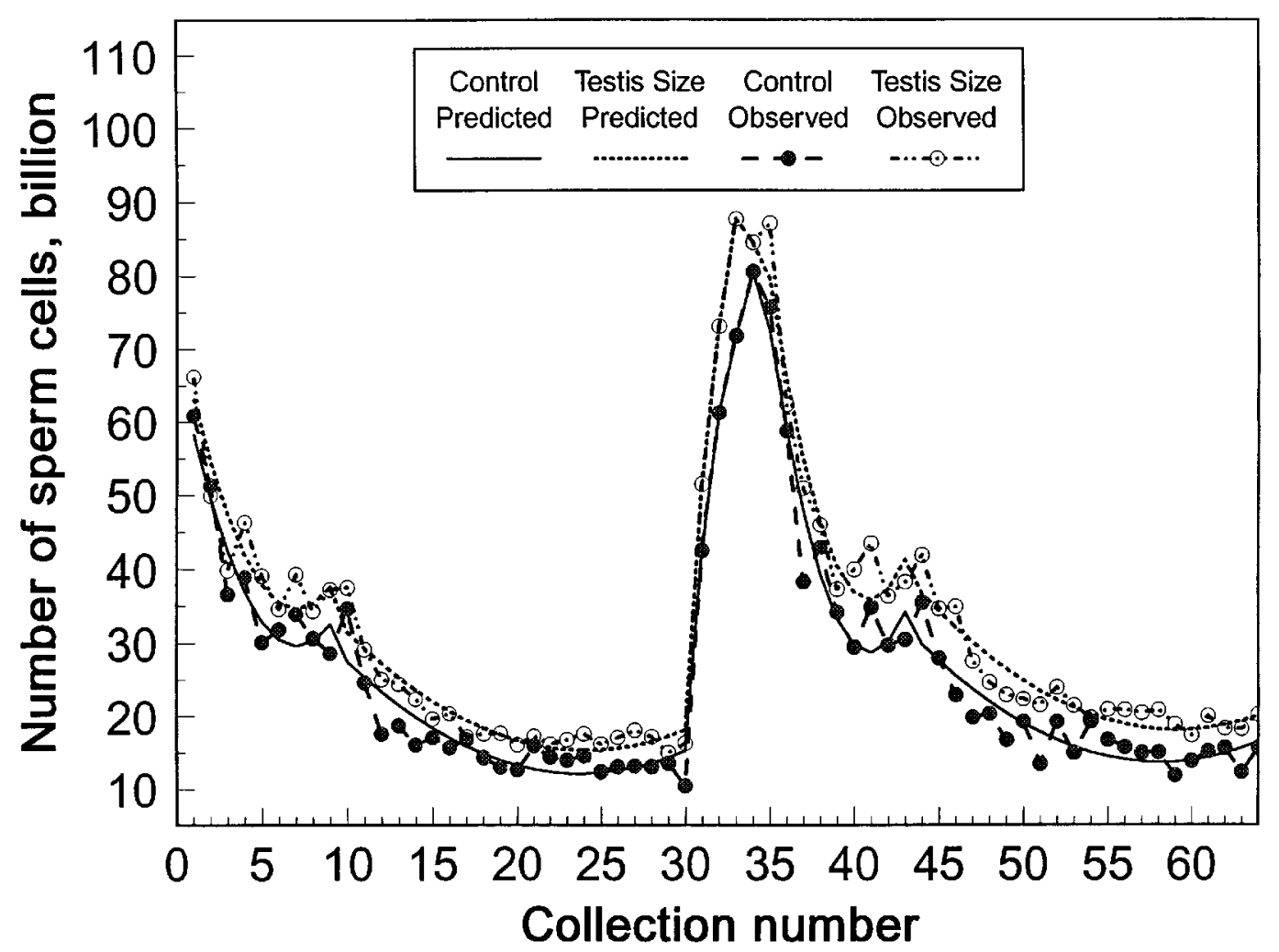

Figure 5. Observed and predicted number of sperm cells in the semen for the select (TS) and control (C) line boars. Collection numbers 1 to 9 and 35 to 43 are TRT1, three semen collections per week, numbers 10 to 30 and 44 to 64 are TRT2, daily semen collections, and 31 to 34 are the rest period, one semen collection per week.

excised testes was 4.3 billion sperm (Table 5), exactly equal to the difference of 4.3 billion sperm in the semen of boars collected daily (Table 4). Mean estimates of daily sperm production were 8.9 and 13.2 billion sperm for $\mathrm{C}$ and TS boars, respectively (Table $5)$. These values are somewhat less than the lower plateaus of number of sperm in the semen (Figure 5).

High correlations of testicular size with sperm output have been found in swine (Wilson et al., 1977; Egbunike and Elemo, 1978; Neely et al., 1980; Fent et al., 1983), sheep (Knight 1977, 1984), and cattle (Hahn et al., 1969; Almquist et al., 1976; Coulter et al., 1976; Neely et al., 1982). None of the studies compared lines that differed in testis size due to selection.

Rathje et al. (1995) compared daily sperm production and efficiency of sperm production in TS and C boars, the same lines used in the present experiment, from Generations 8 and 9. Daily sperm production was greater in TS boars and it increased at a faster rate at

Table 6. Variance components, standard deviation, and repeatability of traits ${ }^{\mathrm{a}}$

\begin{tabular}{|c|c|c|c|c|c|c|c|c|c|c|}
\hline \multirow[b]{2}{*}{ Trait } & \multicolumn{5}{|c|}{ TRT1: three collections per week } & \multicolumn{5}{|c|}{ TRT2: daily collections } \\
\hline & $\hat{\sigma}_{\mathrm{B}}^{2}$ & $\hat{\sigma}_{\mathrm{AB}}^{2}$ & $\hat{\sigma}_{\mathrm{R}}^{2}$ & SD & $\mathrm{R}_{\mathrm{e}}$ & $\hat{\sigma}_{\mathrm{B}}^{2}$ & $\hat{\sigma}_{\mathrm{AB}}^{2}$ & $\hat{\sigma}_{\mathrm{R}}^{2}$ & $\mathrm{SD}$ & $\mathrm{R}_{\mathrm{e}}$ \\
\hline $\begin{array}{l}\text { Semen } \\
\text { volume, } \mathrm{mL} \\
\text { Sperm }\end{array}$ & $1,250.1$ & 258.3 & 831 & 48.4 & .53 & 864.5 & 126.4 & 529.4 & 39 & .57 \\
\hline $\begin{array}{l}\text { motility, \% } \\
\text { Abnormal }\end{array}$ & 16.0 & 9.3 & 16.9 & 6.5 & .38 & 37.2 & 3.4 & 28.8 & 8.3 & .54 \\
\hline $\begin{array}{l}\text { sperm, \% } \\
\text { Sperm concentration, }\end{array}$ & 18.8 & 8.9 & 4.0 & 5.6 & .59 & 31.7 & 6.5 & 4.4 & 6.5 & .74 \\
\hline $\begin{array}{l}\mathrm{million} / \mathrm{mL} \\
\text { Total no. of }\end{array}$ & $2,943.3$ & 471.4 & $3,974.4$ & 86 & .40 & $1,286.3$ & 199.7 & $1,966.9$ & 58.8 & .37 \\
\hline sperm, billion & 45.5 & 0 & 126 & 13.1 & .26 & 8.3 & 4.2 & 37.9 & 7.1 & .16 \\
\hline
\end{tabular}

$\mathrm{a} \hat{\sigma}_{\mathrm{B}}^{2}, \hat{\sigma}_{\mathrm{AB}}^{2}$, and $\hat{\sigma}_{\mathrm{R}}^{2}$ are components of variance for boar, boar $\times$ age, and residual, respectively; $\mathrm{SD}=$ standard deviation, $\mathrm{R}=$ repeatability. 
younger ages than in $C$ boars. The difference was due largely to differences in size of testes, but a difference in efficiency of sperm production also was found. Rathje et al. (1995) expressed efficiency of sperm production as daily sperm production/parenchymal weight and found an advantage of 3.2 million sperm per gram for TS boars. The difference in efficiency was established during the period of pubertal development and was maintained to an age of $450 \mathrm{~d}$. The average advantage of TS boars compared to $C$ boars was 3.5 billion sperm per day compared to the difference of 4.3 billion sperm found in the present study. The same calculations made from data in Table 5 result in an advantage for TS boars compared to $C$ boars of 6.1 million sperm per gram of parenchymal tissue. Therefore, the advantages of TS boars compared to $C$ boars in concentration of sperm and number of sperm in the semen are attributed jointly to larger testes and to greater output of sperm per gram of parenchymal tissue.

\section{Implications}

Selection for increased size of testes in 150-d-old boars is an effective way to increase concentration of sperm in the semen and total number of sperm per ejaculate. The emphasis to give testis size in a selection program depends on current boar fertility relative to other economic traits. Consideration should be given to including testis size in the selection objective in sire lines when boars are used predominantly in artificial insemination programs.

\section{Literature Cited}

Almquist, J . O., R. J . Branas, and K. A. Barber. 1976. Postpuberal changes in semen production of Charolais bulls ejaculated at high frequency and the relation between testicular measurements and sperm output. J. Anim. Sci. 42:670.

Amann, R. P. 1981. A critical review of methods for evaluation of spermatogenesis from seminal characteristics. J . Androl. 2:37.

Amann, R. P., and J. O. Almquist. 1961. Reproductive capacity of dairy bulls. I. Technique for direct measurement of gonadal and extra-gonadal sperm reserves. J. Dairy Sci. 44:1537.

Amann, R. P., and J . O. Almquist. 1962. Reproductive capacity of dairy bulls. VI. Effect of unilateral vasectomy and ejaculation frequency on sperm reserves: Aspects of epididymal physiology. J. Reprod. Fertil. 3:260.

Coulter, G. H., T. R. Rounsaville, and R. H. Foote. 1976. Heritability of testicular size and consistency in Holstein bulls. J . Anim. Sci. 43:9.

Egbunike, G. N., and A. O. Elemo. 1978. Testicular and epididymal sperm reserves of crossbred boars raised and maintained in the humid tropics. J. Reprod. Fertil. 54:245.

Fent, R. W., R. P. Wettemann, and R. K. J ohnson. 1983. Breed and heterosis effects on testicular development and endocrine function of puberal boars. J. Anim. Sci. 57:425.

Hahn, J., R. H. Foote, and E. T. Cranch. 1969. Tonometer for measuring testicular consistency of bulls to predict semen quality. J. Anim. Sci. 29:483.

J ohnson, R. K., G. R. Eckardt, T. A. Rathje, and D. K. Drudik. 1994 Ten generations of selection for predicted weight of testes in swine: Direct response and correlated response in body weight, backfat, age at puberty, and ovulation rate. J. Anim. Sci. 72: 1978.

Knight, T. W. 1977. Methods for the indirect estimation of testes weight and sperm numbers in Merino and Romney rams. N.Z. J . Agric. Res. 20:291.

Knight, T. W. 1984. Testicular growth and size in rams from flocks of different reproductive potential. N.Z. J . Agric. Res. 27:179.

Legault, C., J. Gruand, and F. Oulion. 1980. Development and genetic value of an in vivo method of estimating testis weight in young boars. Anim. Breed. Abstr. 48:26.

Lubritz, D., B. J ohnson, and O. W. Robison. 1991. Genetic parameters for testosterone production in boars. J. Anim. Sci. 69:3220.

Neely, J . D., B. H. J ohnson, E. U. Dillard, and O. W. Robison. 1982. Genetic parameters for testes size and sperm number in Hereford bulls. J. Anim. Sci. 55:1033.

Neely, J. D., B. H. J ohnson, and O. W. Robison. 1980. Heterosis estimates for measures of reproductive traits in crossbred boars. J . Anim. Sci. 51:1070.

Rathje, T. A., R. K. J ohnson, and D. D. Lunstra. 1995. Sperm production in boars after nine generations of selection for increased weight of testis. J. Anim. Sci. 73:2177.

SAS. 1992. SAS/STAT ${ }^{\circledR}$ U ser's Guide (Release 6.08). SAS Inst. Inc., Cary, NC.

Sorensen, A. M. 1979. Animal Reproduction Principles and Practices. McGraw-Hill Publishing Co., New York.

Swierstra, E. E. 1971. Sperm production of boars as measured from epididymal sperm reserves and quantitative testicular histology. J . Reprod. Fertil. 27:91.

Wilson, E. R., R. K. J ohnson, and R. P. Wettemann. 1977. Reproductive and testicular characteristics of purebred and crossbred boars. J. Anim. Sci. 44:939.

Young, D. C., R. H. Foote, A. R. Turkheimer, and H. D. Hafs. 1960 A photoelectric method for estimating the concentration of sperm in boar semen. J. Anim. Sci. 19:20.

Young, L. D., K. A. Leymaster, and D. D. Lunstra. 1986. Genetic variation in testicular development and its relationship to fe male reproductive traits in swine. J. Anim. Sci. 63:17. 